Zabytkoznawstwo i Konserwatorstwo XXXIX, Toruń 2010

Tomasz Kozielec

Uniwersytet Mikołaja Kopernika w Toruniu

\title{
Niektóre operacje technologiczne przyczyniające się do powstawania wad i nietrwałości skór wyprawionych (część 1)
}

\section{Wprowadzenie}

Ckóra jest materiałem najbliższym ciału, który jako jeden z pierwszych, J może nawet i pierwszy, towarzyszy człowiekowi od pradziejów. Odzienie ze skóry wzmiankowane jest już w pierwszej księdze Biblii ${ }^{1}$. Początkowo stosowano wyroby skórzane niegarbowane, z okrywą włosową. Wypraktykowanie nowego sposobu jej preparowania poprzez garbowanie było zapewne dziełem przypadku - taka była historia większości wynalazków. Jedną z najstarszych metod garbowania było zadymianie skór - dym zawiera m.in. aldehyd mrówkowy, czyli związek garbujący kolagen. Przypuszcza się, że zjawisko to zaobserwowano na skórach wędzonych wraz z mięsem w dymie ogniska². Jako inne przykłady znane i stosowane od bardzo długiego czasu można wymienić: garbowanie roślinne, zakwasowe, tłuszczami czy mineralne (za pomocą ałunu). Ponieważ skóra garbowana ma bardzo wiele praktycznych cech użytkowych (m.in. wielce pożądaną odporność na wodę i procesy gnilne), upowszechnienie się wyrobów garbowanych nastąpiło niemal w każdym zakątku świata. Specjalnie nie używam tutaj słowa „rozpowszechniło się", gdyż sztuka ta (jakkolwiek często prymitywna) została wypraktykowana

1 Ksiega Rodzaju 3, 21.

2 K. J. Bieńkiewicz, Fizykochemia wyprawy skór, Warszawa 1986, s. 378. 
przez różne ludy zupełnie niezależnie. Poprzez tysiąclecia technologia wyprawy skór ulegała zmianom - licznym i rozmaitym udoskonaleniom technicznym. Wykorzystanie skóry już w prehistorii i starożytności budzi w nas podziw dla wielkiej pomysłowości człowieka³. Garbarstwo było jednym z najważniejszych rzemiosł, które dawało wyroby powszechnie używane jako odzież i obuwie, oporządzenie dla myśliwych, cześci maszyn, przedmioty umożliwiające transport, sprzęt i oporządzenie wojskowe, namioty, wyposażenie wnętrz mieszkalnych oraz wiele innych przedmiotów ${ }^{4}$. Warto zwrócić uwage na zastosowanie skóry do produkcji pasów pędnych do maszyn, gońców czółenkowych, a nawet kół zębatych ${ }^{5}$. Wielka rewolucja technologiczna nastąpiła w XIX stuleciu - garbarstwo zaczęło przeradzać się w wielki przemysł. Spośród wielu ważnych wydarzeń z historii tego rzemiosła można zwrócić uwage m.in. na takie fakty, jak: 1727 rok - pierwsza fabryka skór w Polsce (Walter Pfeiffer, Warszawa); 1794 rok - pierwsze użycie brzeczek roślinnych zamiast kory i wody; 1801 rok - pierwszy podręcznik - Zasady sztuki garbowania (H. Davy, Anglia); 1867 rok - wprowadzenie pierwszych bębnów garbarskich; 1874 rok - powstanie w Wiedniu pierwszej szkoły garbarstwa i zakładu badawczego (założyciel W. Eitner); lata 1818-1939 - pierwsze podręczniki garbarstwa w języku polskim6; 1897 rok - powołanie pierwszego Międzynarodowego Stowarzyszenia Chemików Przemysłu Skórzanego (wydawało ono własne czasopismo naukowe - „Collegium”) ${ }^{7}$. Nie sposób pominąć ważnego faktu, że poważnym bodźcem do prac nad rozwojem technologii garbarstwa były wojny. Skóra była przez wieki materiałem, który umożliwiał ze względów technicznych prowadzenie szeregu

3 R. Reed, Ancient Skins, Parchments and Leathers, London-New York 1972; R. J. Forbes, Studies in Ancient Technology, vol. 5, Leiden 1966, s. 1-67; T. Kozielec, Od prostych dziet rzemieślników do przepychu: wyroby pochodzenia zwierzęcego w życiu codziennym i kulturze ludów biblijnych, „Nowy Filomata”, 2007, nr 2, s. 137-146.

4 O. Rodziewicz, Podstawy technologii garbarstwa, „Skrypty Uczelniane Politechniki Świętokrzyskiej”, nr 52, Kielce 1978, s. 5.

5 Goniec czólenkowy jest to młotek ze skóry, który uderza w czółenko tkackie, zmuszając je do szybkiego przelotu wraz z wątkiem przędzy. J. Janicki, Pasy pęne i artykuty techniczne ze skóry, Warszawa 1952.

6 O. Rodziewicz, op. cit., s. 12-13.

7 T. Persz, Technologia wyprawy skór, cz. 1: Garbowanie, Warszawa 1977, s. 8. 
działań zbrojnych - jako wyrób wytrzymały, solidny, elastyczny, przepuszczający powietrze, a jednocześnie odporny na deszcz i błoto. Stosowano ją na elementy machin wojennych, na obuwie, okrycie i wyposażenie dla wojska czy zwierząt ${ }^{8}$.

W XIX stuleciu, znanym jako wiek wielkiej rewolucji przemysłowej, opracowano liczne nowe metody wyprawy skór oraz znacznie przyspieszono poszczególne procesy technologiczne. Było to możliwe m.in. dzięki zastosowaniu mocniej oddziałujących na skórę chemikaliów oraz wprowadzeniu odpowiednich urządzeń - te istotne zmiany znacznie skróciły czas wyprawy skór. Nie pozostało to jednak bez wpływu na trwałość gotowych wyrobów. Omówienie wszystkich czynników technologicznych wpływających na pogorszenie się jakości i trwałości skóry wymagałoby bardzo obszernego opracowania. Dlatego też w niniejszej publikacji zostaną opisane tylko niektóre, wybrane czynniki. Konserwator zabytków podczas dokonywania oceny stanu ich zachowania oraz analizowania przyczyn zniszczeń wyrobów skórzanych nie może skupiać się głównie na przyczynach zewnętrznych, będących skutkiem oddziaływań mechanicznych czy zanieczyszczeń powietrza, ale musi koncentrować się także na przyczynach technologicznych - o tym pamięta się nie zawsze. Gdy jest mowa o starzeniu się skóry, priorytetowo porusza się kwestię nadmiernej kwasowości skóry, będącej skutkiem zanieczyszczeń powietrza, zwłaszcza tlenkami siarki. Słusznie - jest to jedna z głównych, najistotniejszych przyczyn jej niszczenia, ale nie jedyna. Warto omówić te pozostałe (przynajmniej niektóre) czynniki pogarszające właściwości, zaistniałe jeszcze podczas warsztatu mokrego, garbowania oraz wykończania skóry.

\section{Technologia a jakość i trwałość skóry}

Pojęcie „trwałości skóry” jest względne w zależności od tego, czy jest używane przez konserwatorów, czy producentów skór garbowanych bądź wytwórców

8 J. W. Waterer, Leather and the Warrior. An account of the importance of leather to the fighting man from the time if ancient Greeks to World War II, Northampton 1981; J. Centek, Reichsheer 1921-1926. Organizacja, uzbrojenie, umundurowanie i wyszkolenie, praca doktorska napisana pod kier. prof. dr. hab. W. Rezmera, Zakład Historii Wojskowej UMK, komputeropis, Toruń 2008, s. 270-314. 
szerokiego asortymentu wyrobów skórzanych. O ile kiedyś wyrobem skór zajmowali się mistrzowie dbający szczególnie o rzetelność warsztatową (a sztuka okrywana tajemnicą rodzinną przechodziła z ojca na syna), o tyle wymogi współczesnej ekonomii uczą przede wszystkim pojmowania trwałości skóry pod kątem użytkowości - dla klienta. Nasuwa się tutaj refleksja: jaka będzie wytrzymałość skór przerabianych masowo, a nawet tych najbardziej wytwornych, najbardziej eleganckich, które kiedyś być może zyskają miano zabytku kultury materialnej... Konserwatorzy z doświadczenia wiedzą, że skórzane wyroby (podobnie jak papier, który też przeszedł swoją rewolucję technologiczną) z XIX i XX wieku sprawiają najwięcej niespodzianek oraz problemów konserwatorskich. Są one spowodowane zmianami technologicznymi w ciaggu dwóch ostatnich stuleci. Na jakość i trwałość wyrobu skórzanego rzutują już pierwsze operacje i procesy, takie jak np. sposób uboju, konserwacja zdjętego ze zwierzęcia surowca, transport, moczenie, obróbka chemiczna, enzymatyczna i mechaniczna - bardzo ważne zabiegi przygotowujące skóre do garbowania. Ponadto o jej jakości i trwałości decydują sposoby garbowania oraz szereg zabiegów związanych z jej wykończaniem. Jak podaje Tadeusz Persz, takie (przykładowe) czynniki, jak: współczynnik kąpielowy (wskazuje na wymaganą objętość roztworu, w którym przebiega proces, w stosunku do masy skór; jest on określany symbolem $K$ ), temperatura, ilość (stężenie) stosowanych związków oraz czasy trwania poszczególnych procesów, należą do wspólnych czynników, od których zależy jakość wyprawionego wyrobu ${ }^{9}$. Poprzez tysiąclecia wykształciło się bardzo wiele sposobów przygotowywania skór do garbowania, metod garbowania oraz wykończania. Duża liczba technik przerabiania tych surowców na wyprawione zależała od rodzaju skóry i przeznaczenia gotowego wyrobu. Na przykład skóry introligatorskie i galanteryjne wymagały większej dokładności i solidności obróbki niż grube, przeznaczone na wiadra czy podeszwy do obuwia. Wyprawa skór jest sztuką trudna, nieprzyjemna, ale jej owoce potrafią być na tyle piękne, że podziwiamy je do dzisiaj: od kunsztownie zdobionych plecionek sandałów, ozdobnych uprzęży końskich, skórzanych obić krzeseł, obleczeń poduszek, 
poprzez zabawki dziecięce, aż po cudowne oprawy książek czy nacechowane niezwykłą delikatnością białe rękawiczki, tzw. wyprawy glacé.

Pomimo różnic technologicznych w wyprawie skór można wyróżnić wspólne etapy technologiczne, takie jak: 1) pozyskanie surowca ze zwierzęcia (ważne są m.in. rodzaj zwierzęcia, jego wiek oraz kondycja zdrowotna, sposób zdejmowania skóry); 2) tymczasowe zabezpieczenie skóry przed psuciem się (używa się m.in. związków chemicznych hamujących rozwój drobnoustrojów lub niszczących je); 3) szereg zabiegów chemicznych, enzymatycznych i mechanicznych mających na celu przygotowanie skóry do garbowania (m.in. usuwanie włosów wraz z cebulkami oraz naskórka, usuwanie z tkanki skórnej zbędnych składników pozakolagenowych, dokładne usunięcie zbędnych, spodnich warstw skóry, wyrównanie jej grubości, odwapnianie, wytrawianie itp.); 4) garbowanie, czyli wprowadzanie do tkanki skórnej odpowiedniej ilości związków garbujących kolagen (związki te nadają skórze charakterystyczne cechy wyrobu wygarbowanego); 5) szereg zabiegów wykończających skórę w zależności od przeznaczenia. Jest to oczywiście schemat bardzo uogólniony. Na każdym etapie obróbki skóry istnieją kluczowe zabiegi technologiczne wpływające na jakość i trwałość skór. Powyższe uwagi można podsumować następującym zdaniem: O trwałości i jakości skóry nie decyduje tylko główny etap wyprawy skór - garbowanie, ale szereg zabiegów poprzedzających go, a także szereg zabiegów składających się na wykończanie skóry.

Czym jest termin „wyprawa skór”, bardzo czytelnie zdefiniował znakomity specjalista z dziedziny garbarstwa - Wiktor Lasek: „Pod określeniem wyprawa skór rozumie się proces przemiany skór surowych w skóry wyprawione. Na wyprawę skór składa się ok. 25 jednostkowych procesów natury chemicznej, biochemicznej, fizykochemicznej, fizycznej i mechanicznej"10. Cytowane opracowanie W. Laska jest wciąż na rynku polskim jednym z najbardziej przydatnych kompendiów wiedzy na temat wyprawy skór także dla konserwatorów zabytków skórzanych. Do bardzo cennych publikacji z zakresu technologii skóry wydanych w języku polskim należą prace Edwarda Krzywickiego. Aby przybliżyć jeszcze bardziej czytelnikom termin „wypra-

10 W. Lasek, Kolagen. Chemia i wykorzystanie, Warszawa 1978, s. 130. 
wa skóry", warto przedstawić jej etapy na przykładzie skór galanteryjnych garbowania roślinnego. Są one następujące: 1) moczenie skóry surowej, 2) rozluźnianie obsady włosa i roztwieranie skóry (roztwieranie jest procesem modyfikacji tkanki skórnej poprzez traktowanie jej związkami zasadowymi, przede wszystkim $\mathrm{Ca}(\mathrm{OH})_{2}$ ), 3) odwłosianie, 4) mizdrowanie (ścinanie od strony mizdry tkanki mięsnej), 5) egalizowanie, 6) wyciskanie brudu, 7) odwapnianie i wytrawianie (wytrawianie to proces enzymatycznej obróbki), 8) garbowanie roślinne, 9) wyżymanie, 10) struganie (wyrównanie grubości skór od strony mizdry metodą skrawania), 11) wymywanie, 12) bielenie, 13) dogarbowywanie, 14) natłuszczanie, 15) wyżymanie, 16) wygładzanie, 17) suszenie, 18) klimatyzowanie, 19) zmiękczanie, 20) wiórkowanie (wyrównywanie i wygładzanie mizdry za pomocą tzw. wiórkownicy), 21) okrawanie, 22) apreturowanie, 23) nabłyszczanie, 24) prasowanie, 25) groszkowanie (jedna z operacji zmiękczania skóry). Każdy z tych etapów wymaga dużej dokładności, a im staranniej i ostrożniej zabiegi te przeprowadzano, tym bardziej trwały stawał się gotowy produkt.

W pierwszej części artykułu zostaną omówione: jakość (kondycja) skóry na zwierzęciu, konserwowanie (zabezpieczanie przed psuciem) oraz moczenie i płukanie. Zabiegi te podobnie jak i dalsze, które znajdą się w drugiej części opracowania, zostana przedstawione jedynie w zarysie, albowiem technologia wyprawy skór jest zagadnieniem niezwykle złożonym i obszernym, zwłaszcza jeśli ukazuje się ją na przestrzeni stuleci. Na przykład omówienie samych tylko sposobów konserwacji skór musiałoby zająć co najmniej kilkudziesięciostronicowe opracowanie.

\section{Jakość (kondycja) skóry na zwierzęciu}

Już na żywym zwierzęciu skóra jest narażona na rozmaite uszkodzenia. Jakość tkanki skórnej zależy od sposobu odżywiania się zwierzęcia. Na przykład zbyt duża ilość tłuszczu w skórze powoduje m.in. jej rozluźnienie oraz zmniejszenie wytrzymałości włókna na rozciąganie. Ważnymi czynnikami niszczącymi są choroby skórne spowodowane rozwojem bakterii, grzybic, owady pasożytnicze, np. larwy gza bydlęcego rozwijającego się w skórze (rys. 2) czy kleszcze, a także rozmaite inne choroby i pasożyty. Dochodzą do tego rany na skórze spowodowane cięciem, np. przez ostre kamienie, suche gałęzie, druty kolczaste, czy otarciami. W pływ na jakość skóry ma nawet nad- 
miar lub brak ruchu zwierzęcia. Na przykład skóra zwierząt hodowlanych przebywających dłuższy czas w oborach bez ruchu jest luźna, mało elastyczna i miękka, a skóra zwierząt przebywających na otwartych przestrzeniach jest gruba i zwarta ${ }^{11}$. Do pierwszych wad pogarszających jakość skóry, a spowodowanych przez człowieka po uboju zwierzęcia, jest sposób jej zdejmowania. Na skutek nieostrożnego i niewłaściwego ściągania skóry tworzą się spękania lica, a ścięcie skóry od strony mizdry wywołuje mechaniczne uszkodzenia w postaci zacięć $i$ „wychwytów” (są to wgłębne, lukowate wcięcia) (rys. 1)12. Głębokie naruszenie tkanki skórnej na jej grubości osłabia oczywiście jej strukture.

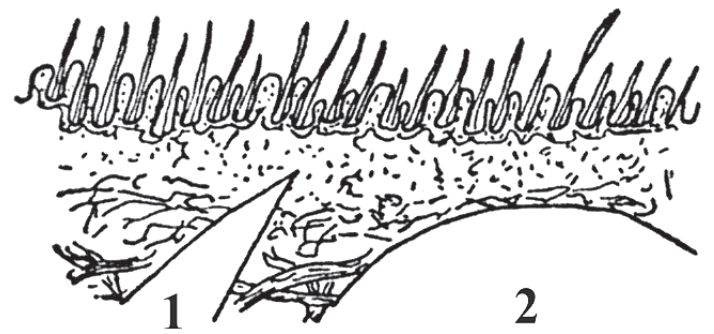

Rys. 1. Wady skóry powstałe podczas zdejmowania skór: 1 - zacięcia, 2 - wychwyty, za: Z. Kowalski, Uszkodzenia i wady skór gotowych. Przyczyny powstawania i sposoby zapobiegania, Warszawa 1953, s. 14

\section{Konserwowanie skór (zabezpieczanie przed rozwojem drobnoustrojów)}

Skóra po zdjęciu ze zwierzęcia jest surowcem bardzo nietrwałym. Istnieja dwie drogi postepowania z nią: albo trafia bezpośrednio do warsztatu mokrego, albo zostaje zabezpieczana przed rozwojem mikroorganizmów i wtedy można ją przechowywać nawet przez dłuższy czas (w zależności od sposobu konserwowania). Skóry świeże, niekonserwowane, są nazywane zielonymi (ang. green hides). Trzeba podkreślić tutaj niebezpieczny udział drobnoustrojów w niszczeniu zdjętej ze zwierzęcia skóry. Otóż jest ona pokryta bardzo dużą ilością drobnoustrojów pochodzących przede wszystkim z ziemi czy nawozu. Jak podaje W. Lasek, jest to ok. $10^{5}-10^{7}$ drobnoustrojów na jeden gram skóry! Jeśli nie są to bakterie chorobotwórcze, nie szkodzą skórze zwierzęcia za jego życia, ale po uboju natychmiast zaczynają się rozmnażać.

11 Z. Kowalski, Uszkodzenia i wady skór gotowych. Przyczyny powstawania i sposoby zapobiegania, Warszawa 1953, s. 8-17.

12 Ibidem, s. 14. 
Najgroźniejsze są te, które powodują procesy gnilne skóry. Ponadto z chwilą śmierci w skórze zaczynają ujawniać się procesy pośmiertne, m.in. autoliza ${ }^{13}$. Autoliza (samotrawienie) jest to samozniszczenie komórki w wyniku działania własnych enzymów hydrolitycznych (autolizyn) ${ }^{14}$. Skóry na przestrzeni wieków poddawano konserwacji różnymi sposobami. W jednym z opracowań XVIII-wiecznych wspomina się m.in. o soleniu skór samą solą (de morue) bądź solą zmieszaną z ałunem. Bardzo ważny był dodatek tej substancji w dostatecznie dużej ilości, np. większy jej dodatek musiano stosować w okresie zimowym, ponieważ skóry wolniej schły ${ }^{15}$. Obok możliwości konserwowania solami (np. chlorkiem sodu) istnieją inne sposoby, takie jak np. suszenie czy konserwowanie przez piklowanie (sól kuchenna z kwasem mineralnym) ${ }^{16}$. Sól kuchenna jest tanim i powszechnie stosowanym środkiem służącym do zabezpieczenia skór, nie jest ona jednak środkiem bakteriobójczym, hamuje jedynie ich rozwój. Bardzo ważna była czystość chemiczna soli stosowanej do konserwacji. Chodzi o zanieczyszczenia towarzyszące chlorkowi sodu. Jeśli w soli znajduje się zawartość powyżej 0,5\% dodatków w postaci związków wapnia i magnezu (w przeliczeniu na bezwodny siarczan), zaczynają one stymulować wzrost drobnoustrojów, a ponadto powstawanie plam solnych na skórze. Sól nie może zawierać także więcej niż $0,03 \% \mathrm{Fe}_{2} \mathrm{O}_{3}$, ponieważ związki żelaza również powodują tworzenie się plam na skórach ${ }^{17}$. Wywołują one (głównie tlenek i wodorotlenek), jako zanieczyszczenie środków konserwujących, zagarbowanie skóry już podczas konserwacji. Takie zagarbowane miejsca trudno jest dobrze rozmoczyć i zwapnić. Etap wapnienia - niezwykle ważny i znacznie zmieniający właściwości skóry - zostanie opisany w drugiej czesści artykułu. Plamy żelazowe na skórze to niejedyny problem. Sól użyta do konserwacji mogła zawierać także inne szkodliwe zanieczyszczenia, o których warto wspomnieć - duże ziarna gipsu. Gips może być wchłaniany przez

13 W. Lasek, op. cit., s. 161-162.

14 R. Konieczny, Autoliza, [w:] Encyklopedia szkolna. Biologia, Kraków 2005, s. 51.

15 The Art of Tanning and of Currying Leather. With the Processes for Dying Leather Red and Yellow, As practised in Turkey. Collected from the French of Monsieur De La Lande and Others, Dublin 1773, s. 3-5.

16 W. Lasek, op. cit., s. 163-174.

17 Ibidem, s. 163-164. 
skóre jak garbnik, w wyniku czego ulega ona miejscowemu „zagarbowaniu”. Miejsca takie nazywano „plamami gipsowymi” - nie dawały się one dobrze rozmoczyć ani też zwapnić. Znane było także uszkodzenie skór nazywane „plamami ałunowymi”. Ałun ma właściwości garbujące skórę. Jeśli ałun (w postaci miałkiego proszku) był dodatkiem do soli, dobrze wymieszanym, wtedy na całej powierzchni skóry (!) można było stwierdzić zagarbowanie ałunowe. Utrudniało ono lub nawet uniemożliwiało rozmoczenie skór oraz ich wapnienie ${ }^{18}$.

Innym przykładowym sposobem konserwacji skór było i jest suszenie. To sposób stosowany głównie w krajach tropikalnych (skutek braku większych ilości soli na tych terenach). Wadami tej metody jest częste niszczenie skór przez działalność chrząszczy i ich larw, dochodzi też niebezpieczeństwo zakażenia bakteriami waglika ${ }^{19}$, które należą do bardzo groźnych także dla człowieka, gdyż zakażenie przenosi się na ludzi przez zainfekowane zwierzęta bądź produkty pochodzenia zwierzęcego. Ta choroba odzwierzęca jest wywoływana przez bakterię Bacillus anthracis. Z trzech klinicznych postaci wąglika najczęściej występuje postać skórna ${ }^{20}$. Ponadto w przypadku szybkiego suszenia zdarza się, że obie warstwy zewnętrzne schną szybciej niż wewnętrzne. W warstwach wewnętrznych pozostaje więcej wody, która nie może odparowywać (przez zrogowaciałe warstwy zewnętrzne), stąd dochodzi do gnicia skóry ${ }^{21}$. Zakonserwowane skóry można było magazynować. Tutaj też czyhało wiele niebezpieczeństw. Obok takich zagrożeń, jak np. kontakt z zardzewiałymi elementami, zamarznięcie skór, złe ich ułożenie w stosie, rozwój bakterii (szczególnie na skórach źle zakonserwowanych), bardzo dużo szkód mogą powodować gryzonie i owady, takie jak np. skórnik słoniniec. Warto powiedzieć o tych szkodnikach parę słów. Te czarno-brązowe chrząszcze spędzają zimę w szczelinach podłóg i ścianach magazynu, a w przypadku cieplejszych magazynów potrafia prowadzić swą niszczycielską działalność przez cały rok! Za szkody są odpowiedzialne larwy tych owadów, które powoduja powstawanie sieci chodników, kanalików, a nawet

18 Z. Kowalski, op. cit., s. 33-34.

19 W. Lasek, op. cit., s. 172-173.

20 W. Hałdaś, Waglik, [w:] Encyklopedia szkolna. Biologia, Kraków 2005, s. 714-715.

21 Z. Kowalski, op. cit., s. 16. 
dziur. Skórniki atakują wszystkie rodzaje skór suchych, a także uszkadzają skóry suchosolone ${ }^{22}$. Podczas transportu skór również mogło dochodzić do rozmaitych uszkodzeń spowodowanych obecnością zanieczyszczeń (np. piasek, kamyki), kontaktem z elementami zardzewiałymi, czynnikami mechanicznymi powstałymi w wyniku nieodpowiedniego ich zapakowania czy też zapoceniem się skór itp.

\section{Moczenie skóry}

Moczenie jest wstępnym etapem tzw. warsztatu mokrego ${ }^{23}$. Dawniej podkreślano, że każda garbarnia powinna być ulokowana przy brzegu biegnącego potoku, w którym woda nie może być zbyt twarda. Jeśli potok jest szybki, skóry muszą być przymocowane do dwóch słupów w korycie rzeki²4. W celach przemysłowych moczenie przeprowadza się w środowisku wodnym zazwyczaj z rozmaitymi dodatkami przyspieszającymi ten proces oraz środkami zapobiegającymi rozwojowi drobnoustrojów w wodzie. Jak podaje Olgierd Rodziewicz, moczenie odbywa się w kilku etapach, z każdorazową wymianą kapieli. Płukanie wstepne jest przeprowadzane przez 20-30 minut i polega na wymywaniu chlorku sodu użytego do konserwacji skór, znacznej ilości zanieczyszczeń - zwłaszcza bakterii, a także na uwadnianiu zewnętrznych warstw skóry oraz miejsc luźniejszych. Moczenie I jest prowadzone z dodatkiem emulgatorów lub środków zwilżających oraz środków bakteriostatycznych, trwa w bębnie 2-4 godziny. Moczenie II odbywa się w kąpieli świeżej, nowej, z dodatkiem środków zwilżających i bakteriostatycznych, trwa kilkanaście godzin (wliczając postój bębna w nocy), a czasem 1/2 doby (ale w takim przypadku konieczna jest wymiana wody na świeżą ze względu na rozwój bakterii, które i tak rozwijają się mimo stosowanych środków). Opracowano też sposoby przyspieszonego moczenia, skracające czas nawet do 3-4 godzin! W metodach przyspieszonych stosuje się zwykle: podwyższoną temperature, środki powierzchniowo czynne, zwilżające i emulgujące,

22 M. Chojnowski, E. Sikora, Pozyskiwanie i konserwacja skór surowych, Warszawa 1970, s. 137.

23 Prace warsztatu mokrego mają na celu doprowadzenie skóry do takiego stanu, aby mogła być poddana garbowaniu.

24 The Art of Tanning and of Currying Leather, s. 5. 
czynnik ruchu oraz środki bakteriostatyczne ${ }^{25}$. Poprzez użycie dodatków oddziałujących na tłuszcz zawarty w skórze usuwa się także z niej jego nadmiar ${ }^{26}$. Urządzeniami służącymi do moczenia skóry (rys. 3) są: bębny obrotowe (tradycyjne i najbardziej popularne urządzenia stosowane do różnych zabiegów warsztatu mokrego), ale również cytrok (półbeczka, która w górnej cześci ma zamontowane koła łopatkowe poruszające ciecz i skórę) oraz mieszalniki i pralnice ${ }^{27}$. Mechanizacja z jednej strony przyspieszyła poszczególne zabiegi, z drugiej jednak mogła pociągnąć za sobą uszkodzenia skór. Na przykład zbyt szybkie obracanie bębnów powodowało energiczne zgniatanie, łamanie i uderzanie skór o siebie i wpływało niekorzystnie na ich strukturę (zwłaszcza pewnych ich cześci) ${ }^{28}$.
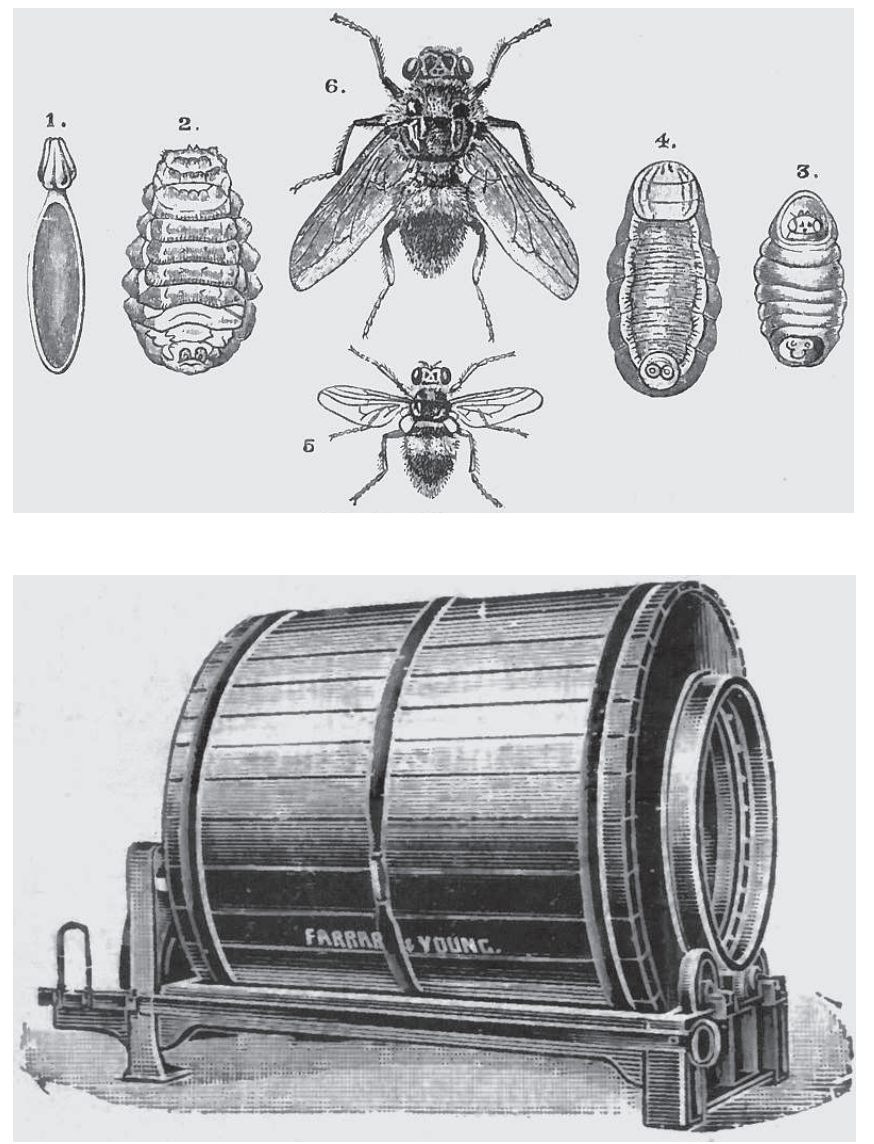

Rys. 2. Giez w różnych stadiach rozwoju, za: H. G. Bennett, The Manufacture of Leather, London 1920, s. 30, „Warble Fly (Hypoderma bovis)"

Rys. 3. Przykład bebna stosowanego w procesie moczenia, za: H. G. Bennett, op. cit., s. 51, „Scotch tumbler”
25 O. Rodziewicz, op. cit., s. 109-111.
26 K. J. Bieńkiewicz, op. cit., s. 275.
27 T. Persz, op. cit., s. 45-51.
28 Z. Kowalski, op. cit., s. 35. 
Moczeniu poddaje się skórę świeżą, w stosunkowo krótkim czasie zdjętą ze zwierzęcia (tzw. skóry zielone), lub zabezpieczaną przed rozwojem mikroorganizmów. Jak już wspominano, zabieg moczenia ma na celu usunięcie niepożądanych składników skóry: krwi, brudu i białek rozpuszczalnych w wodzie, oraz jej nawodnienie. Jeśli skóry są świeżo zdjęte ze zwierzęcia (tzw. zielone) i szybko poddane procesowi moczenia, podstawowym celem zabiegu będzie wymycie ich z niepożądanych składników. W przypadku skór konserwowanych dochodzi jeszcze konieczność usunięcia środka konserwującego. Podczas moczenia tkanka skórna ulega uwodnieniu oraz lekkiemu spęcznieniu ${ }^{29}$. Do usuwanych zanieczyszczeń skóry należą także pasożyty (kleszcze, larwy itp.), piasek czy kamyki ${ }^{30}$ (skóra może być nimi oblepiona wraz z innymi nieczystościami, np. odchodami). Pasożyty żerujące w skórze są w stanie poważnie ją uszkodzić, czasem nawet na dużych powierzchniach. Powoduje to znaczne straty w surowcu. Jednak największym problemem podczas moczenia jest wnoszenie na skórach surowych (tzw. zielonych) wielkiej liczby drobnoustrojów, stąd konieczność stosowania związków hamujących ich szybki rozwój (stosuje się związki bakteriostatyczne lub bakteriobójcze). Jak podaje Krzysztof Bieńkiewicz, w czasie rozmaczania następuje także bardzo szybko wzrost bakterii na skórze zakonserwowanej - to efekt ich przeżycia w postaci przetrwalników ${ }^{31}$. Jak podkreślał Zbigniew Kowalski, niebezpieczeństwo przeniesienia bakterii wąglika jest największe przy skórach suszonych - działanie światła i gorąca nie wystarcza do zabicia drobnoustrojów. Przetrwalniki bakterii uaktywniają się podczas procesu moczenia. Stąd w trakcie moczenia skór podejrzanych o zakażenie waglikiem dodawano np. sublimat jako środek odkażający; jednak dodatek środka odkażającego nie gwarantował zabicia bakterii w skórach ciężkich i grubych oraz zawierających znaczne ilości tłuszczu ${ }^{32}$. Obok konieczności kontrolowania szybkiego rozwoju drobnoustrojów niezwykle ważne jest także skuteczne, równomierne nawodnienie tkanki skórnej. Szczególnie trudno nawadniają się skóry suszone. Skóry źle rozmoczone stwarzaja proble-

\footnotetext{
29 T. Persz, op. cit., s. 42.

30 K. J. Bieńkiewicz, op. cit., s. 274.

31 Ibidem, s. 273.

32 Z. Kowalski, op. cit., s. 32.
} 
my w dalszych procesach wyprawy. Olgierd Rodziewicz podkreślił, że wady i uszkodzenia skór mogące powstać podczas moczenia to zazwyczaj niedostateczny stopień uwodnienia oraz wpływ bakterii (powodują hydrolizę białek skóry). Niewystarczające uwodnienie skóry może skutkować miejscową jej sztywnością, a hydroliza kolagenu objawi się zwiększoną luźnością całej skóry, a nawet ubytkami w tkance (! $)^{33}$. Tak więc ten pierwszy etap - moczenie - może już znacznie pogorszyć właściwości skóry. Dobrze zdawano sobie sprawę z negatywnych skutków tego procesu już od dawna. Dawni mistrzowie zwracali baczną uwage na gnilny zapach skór podczas moczenia, po którym poznaje się ich tendencję do psucia, a także na jakość wody używanej do moczenia, albowiem niektóre rodzaje wód przyczyniają się do szybszego psucia się skór ${ }^{34}$. Persz zalecał stosowanie do moczenia skór wody miękkiej, podkreślał, że niebezpieczna jest woda z jezior i rzek z uwagi na występowanie dużej liczby drobnoustrojów, podobnie jak deszczówka zbierana i długo przechowywana w otwartych zbiornikach ${ }^{35}$. W opracowaniu, którego autorami są J. De Fontenelle oraz F. Malepeyre, znajdziemy szczegółowe informacje na temat rodzajów wód używanych do moczenia. Omówiono w nim skład wód, które potencjalnie mogą być wykorzystane do tego procesu, np. deszczówki, wody ze śniegu, wody rzecznej, z jeziora, wody bagiennej oraz innych, a także podano sposoby ich oczyszczania z niepożądanych składników chemicznych. Przykładowym negatywnym czynnikiem powodującym ciemnienie oraz kruchość skór jest stosowanie wody zawierającej żelazo ${ }^{36}$. Ponieważ związki żelaza (zwłaszcza wodorotlenek) obecne w wodzie używanej podczas moczenia i płukania skór powodują ich zagarbowanie oraz powstawanie plam, zalecano stosowanie wody odżelazionej ${ }^{37}$. Nie tylko poszczególne związki chemiczne występujące w wodzie (w zależności od jej pochodzenia - rzeki, jeziora itp.) są w stanie wpłynąć negatywnie na skórę. Wiele skażonych substancji może mieć deszczówka w miastach. Może w niej

33 O. Rodziewicz, op. cit., s. $111-112$.

34 The Art of Tanning and of Currying Leather, s. 6.

35 T. Persz, op. cit., s. 44.

36 J. De Fontenelle, F. Malepeyre (poprawki i dodatki C. Morfit), The Arts of Tanning, Currying and Leather-Dressing; Theoretically and Practically Considered in all their Details, Philadelphia 1852, s. 158-162.

37 Z. Kowalski, op. cit., s. 33. 
często znajdować się kwas będący wynikiem rozpuszczania się zanieczyszczeń przemysłowych zawierających ditlenek siarki ${ }^{38}$.

Wymienione powyżej czynniki wpływające na pogorszenie jakości skóry oraz jej trwałości nie są jedyne. Nie bez wpływu na skórę pozostają także niektóre środki przyspieszające proces jej moczenia. Ich przykładami są: wielosiarczek sodu, siarczyn sodu, wodorotlenek sodu, chloroamina, podchloryny ${ }^{39}$. Stosowanie środków zaostrzających może doprowadzić do zniszczenia zewnętrznej części włosów, podczas gdy obsada włosów przez spęcznienie alkaliczne uniemożliwia przeniknięcie kąpieli w głąb tkanki skórnej, a także rozluźnienie cebulek włosowych ${ }^{40}$. Zabiegiem, który może mieć negatywny wpływ na jakość i trwałość skóry (jeśli jest błędnie przeprowadzony), jest mizdrowanie skór (mechaniczne usuwanie zbędnych spodnich tkanek skóry - mięśniowej i tłuszczowej). Może on być przeprowadzony w trakcie rozmaczania lub po rozmoczeniu ${ }^{41}$. Jeśli np. skóry były suszone w stadium niedostatecznego rozmoczenia, to błędem była ich przedwczesna obróbka mechaniczna, gdyż mogła prowadzić do mechanicznych uszkodzeń lica skóry oraz łamania włókien ${ }^{42}$.

Przedstawione powyżej w skrócie wybrane błędy występujące w zabiegach warsztatu mokrego mogły być częściowo zniwelowane w dalszych etapach wyprawy. Jednak nierzadko nie udawało się to, dlatego też tak ważne było racjonalne i ostrożne stosowanie poszczególnych operacji i procesów technologicznych.

W drugiej części opracowania zostaną omówione przede wszystkim następujące zagadnienia: wpływ na skóry wapnienia i odwapniania, wytrawianie, niektóre rodzaje garbowania oraz wybrane czynności wykończania skór, a także niekorzystne skutki zastosowania maszyn przy wyprawie skóry.

38 Ibidem, s. 23.

39 T. Persz, op. cit., s. 45.

40 Z. Kowalski, op. cit., s. 32.

41 K. J. Bieńkiewicz, op. cit., s. 276.

42 Z. Kowalski, op. cit., s. 35. 


\section{Summary}

\section{Some technological procedures that may contribute to the failures and imperfection of tanned leather (part 1)}

Tanned leather is one of the oldest materials, that has been used by mankind. Throughout the ages leather has been used for clothing and footwear, leather haberdashery, elements of machinery, book binding etc. Before the hide becomes a ready to use product (that is tanned, or dressed leather) must undergo several different processes, such as: I. introductory procedure - preserving (with salts, by drying etc.), washing and soaking in water, liming (removing of hair-coat and "opening" the hide) and de-liming as well as the accompanying mechanical treatment, curing and so on (depending on the tanning method); II. tanning (with organic or mineral tanners, with smoke etc.); III. finishing treatment, such as oiling, drying, whitening, tinting etc.

In $19^{\text {th }}$ century the art of tanning leather has been transformed into an industry. To speed-up particular operations one started to use various machines and more aggressive chemicals were used. Acceleration of tanning processes negatively influenced the quality and durability of leather. During tanning occur many factors negatively influencing the properties of ready product. For example preserving the hides by drying may cause their brittleness, and during soaking bacteria, attacking collagen may develop in excessive amounts. 